\title{
Radiobiogeochemical research of the Karakol River basin in the Issyk-Kul region, Kyrgystan
}

\author{
Kymbat Ibraeva ${ }^{1}$, and Bakyt Kaldybaev ${ }^{1, *}$ \\ ${ }^{1}$ Issyk-Kul State University, 722200 Karakol, Abdrakhmanova str.103, Kyrgyzstan
}

\begin{abstract}
This paper presents the results of radioecological research of the Karakol River basin in Issyk-Kul region of Kyrgystan. The Karakol River has a snow-glacier feed, the chemical concentration of the water is slightly mineralized and it is of calcium-hydrocarbonate-sulfate type. The concentration of radionuclide was determined in soil, water, river bottom sediments and the city of Karakol. The values of concentrations are varied within the natural regional background, but a significant increase of the specific activity of radionuclides was observed in the estuary zone of the river. The map of the level of the exposure dose of the territory of the city of Karakol was compiled with the help of the computer program "Surfer-12".
\end{abstract}

\section{Introduction}

The Karakol River originates from the Karakol Glacier from the northern slope of Teskey Ala-Too at an altitude of 5200 meters and runs into the Issyk-Kul Lake. The length of the river is about $50 \mathrm{~km}$, the catchment area is $394 \mathrm{~km} 2$ (Fig. 1). The Karakol River refers to the rivers of snow and glacier feeding, the mode of its flow is closely connected with the air temperature regime, a secondary role in the feeding of the river acts on atmospheric precipitation and groundwater, and the last feeding refers to its up and down stream. In the mountain areas the river has a turbulent mountain stream and it becomes calmer on the cone of removal. According to the chemical concentration of the water of the Karakol River, it is slightly mineralized as a calcium-hydrocarbonate-sulfate type water [1].

Karakol City is located in the lower reaches of the Karakol River. The city is the administrative and cultural center of the Issyk-Kul region, the population was 73,000 people in 2016. The city is known in the CIS and far abroad for its recreational opportunities. The sustainable development program of region is associated with the assessment of the radiation impact on the population. But the lack of public data in this area generates radiophobia among the population, which in turn makes it difficult to create a positive image of the Kyrgyz Republic, in which a significant part of economic development is related to tourism.

\footnotetext{
*Corresponding author: k_bakyt@ @rambler.ru
} 


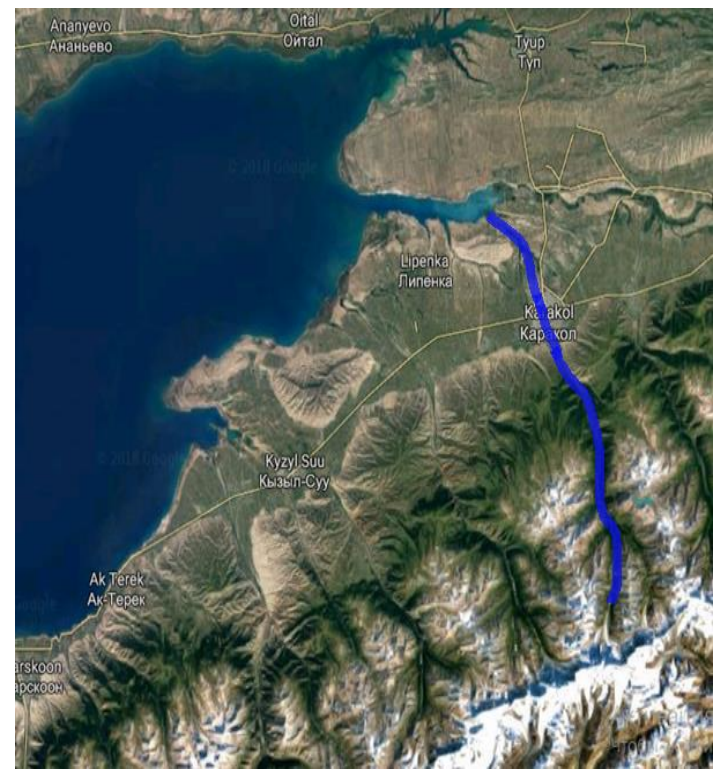

Fig. 1. Hydrography of the Karakol River.

\section{Methods of research}

For this study, we obtained 30 samples of water, 15 samples of bottom sediments and 25 samples of soil for radioecological research. Sampling was carried out according to generally accepted procedures [2]. For the gamma survey of the area, we used a dosimeter - the radiometer DKS-96. The measurements were carried out in accordance with the instructions for a ground-based survey of the radiation situation [3]. Alpha-beta radiometer, UMF-2000, was used to measure the total alpha and beta activity of water samples after their concentration. The determination of radionuclides in samples of sediments and soil was carried out by gamma spectrometry using the Canberra gamma spectrometer (model GX4019).

\section{Results and discussion}

The results of water samples analyzes of the Karakol River showed that the levels of the total alpha activity range from 0.06 to $0.10 \mathrm{~Bq} / \mathrm{l}$ and beta activity range from 0.06 to 0.12 $\mathrm{Bq} / \mathrm{l}$ (Table 1).

Table 1. Total $\alpha$ - and $\beta$-activity of radionuclide in the water of the Karakol River.

\begin{tabular}{|c|c|c|c|c|}
\hline \multirow{2}{*}{ Place of sampling } & \multirow{2}{*}{$\mathrm{N}$} & $\mathrm{E}$ & \multicolumn{2}{|c|}{$\begin{array}{c}\text { Total activity of } \\
\text { radionuclide (Bq/l) }\end{array}$} \\
\cline { 4 - 5 } & & & $\alpha$-activity & $\beta$ - activity \\
\hline 1. Karakol Nature Park & $42^{0} 42.158$ & $78^{0} 43.636$ & $0.06 \pm 0,02$ & $0.10 \pm 0,01$ \\
\hline 2. Karakol Nature Park & $42^{0} 43.041$ & $78^{0} 42.583$ & $0.09 \pm 0,02$ & $0.06 \pm 0,01$ \\
\hline $\begin{array}{c}\text { 3. Karakol, } \\
\text { (the bridge of Karasayev street) }\end{array}$ & $42^{0} 47.358$ & $78^{0} 38.785$ & $0.08 \pm 0,02$ & $0.09 \pm 0,01$ \\
\hline $\begin{array}{c}\text { 4. Karakol, } \\
\text { (the bridge of Toktogul street) }\end{array}$ & $42^{0} 48.448$ & $78^{0} 38.114$ & $0.08 \pm 0,02$ & $0.10 \pm 0,01$ \\
\hline 5. Karakol City (the road to the lake) & $42^{0} 55.791$ & $78^{0} 34.413$ & $0.10 \pm 0,02$ & $0.12 \pm 0,01$ \\
\hline $\begin{array}{c}\text { 6. Karakol River } \\
\text { (the mouth of the river) }\end{array}$ & $42^{0} 57.985$ & $78^{0} 30.019$ & $0.10 \pm 0,02$ & $0.12 \pm 0,01$ \\
\hline
\end{tabular}


There is an insignificant increase in activity of radionuclides in the water along the relief of the terrain to the mouth of the river. In accordance with the norms of SanPiN 2.1.4.002-03, the reference levels for drinking water of alpha emitters are $0.1 \mathrm{~Bq} / \mathrm{l}$, beta emitters - $1 \mathrm{~Bq} / \mathrm{l}$.

The concentration of $U$ and other radionuclides in the silt-clay fractions of the bottom sediments of the Karakol River are within the limits of background values. An insignificant increase in the specific activity of radionuclides is observed in the estuary zone of the river (Table 2).

Table 2. Radionuclide concentration of silt-clay fractions of the Karakol River sediments.

\begin{tabular}{|c|c|c|c|c|c|c|c|c|}
\hline \multirow{2}{*}{ Place of sampling } & \multicolumn{2}{|c|}{ U/Th-234 } & \multicolumn{2}{c|}{$\begin{array}{c}\text { Th-232/ } \\
\text { Ac-228 }\end{array}$} & \multicolumn{2}{c|}{ K-40 } & \multicolumn{2}{c|}{ Cs-137 } \\
\cline { 2 - 10 } & $\mathrm{Bq} / \mathrm{kg}$ & \pm & $\mathrm{Bq} / \mathrm{kg}$ & \pm & $\mathrm{Bq} / \mathrm{kg}$ & \pm & $\mathrm{Bq} / \mathrm{kg}$ & \pm \\
\hline 1. Karakol Nature Park & 28.7 & 3.5 & 23.1 & 3 & 700 & 25.9 & 0.8 & 0.03 \\
\hline 2. Karakol Nature Park & 32.4 & 2.3 & 33.2 & 2.3 & 720 & 26.6 & 1.3 & 0.05 \\
\hline $\begin{array}{c}\text { 3. Karakol, } \\
\text { (the bridge of Karasayev } \\
\text { street) }\end{array}$ & 14.8 & 1.3 & 41.8 & 2.3 & 676 & 25.1 & 1.9 & 0.07 \\
\hline $\begin{array}{c}\text { 4. Karakol, } \\
\text { (the bridge of Toktogul street) }\end{array}$ & 24.0 & 2.0 & 54.8 & 3.1 & 704 & 26.1 & 2.1 & 0.11 \\
\hline $\begin{array}{c}\text { 5. Karakol River } \\
\text { (the mouth of the river) }\end{array}$ & 50.4 & 2.3 & 75.8 & 4.2 & 977 & 35.8 & 0 & - \\
\hline
\end{tabular}

The level of the radiation background by gamma radiation in the territory of the city of Karakol varies in the limit of 16-30 microR/h (Fig. 2). According to the Law of the Kyrgyz Republic Technical Regulation" On Radiation Safety", the dose rate of gamma radiation should not exceed $30 \mathrm{microR} / \mathrm{h}$ in the adjacent territory.

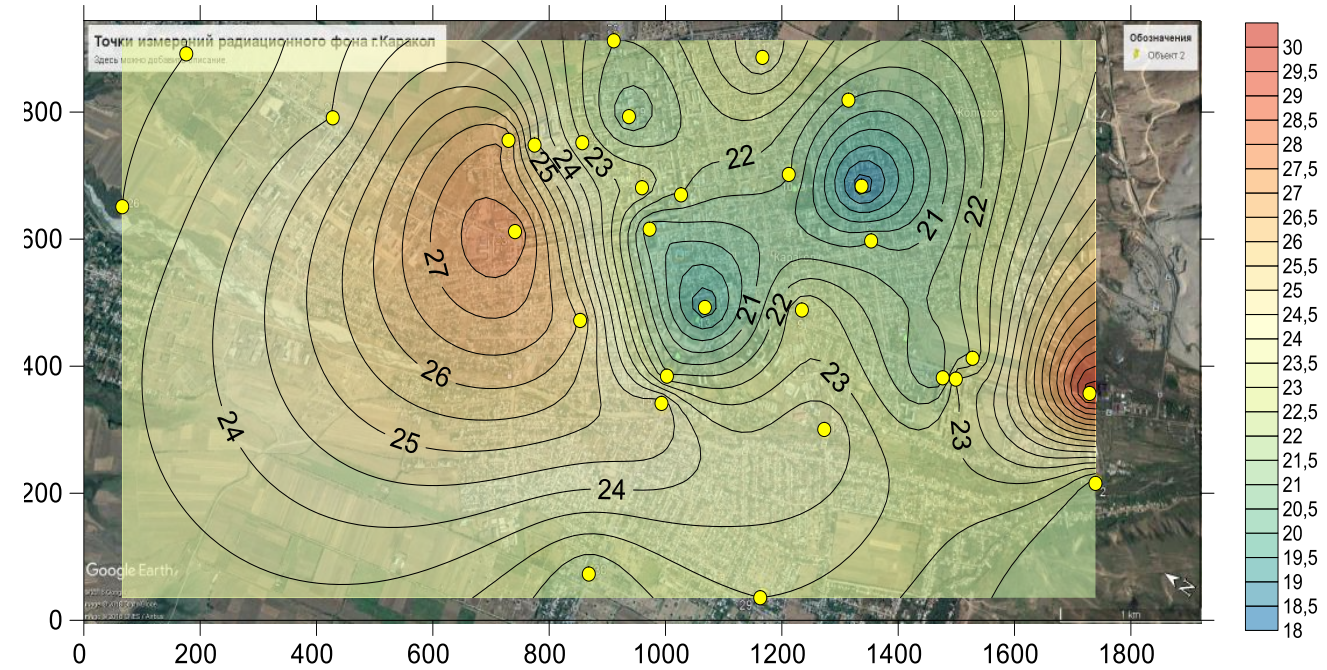

Fig. 2. The card capacity of the exposure dose of gamma radiation in the territory of the city of

Karakol, using the program Surfer 11 (microR/h).

The variation of the uranium concentrations for normal soils is limited to <12-100 $\mathrm{Bq} / \mathrm{kg}$, and for uranium anomalies, $600-12500 \mathrm{~Bq} / \mathrm{kg}$. Clark $238 \mathrm{U}$ in soil is $12.4 \mathrm{~Bq} / \mathrm{kg}$, range $(10-50 \mathrm{~Bq} / \mathrm{kg})$ with an average of $25 \mathrm{~Bq} / \mathrm{kg}$ [4,5]. The accumulation of uranium in various types of soils is determined mainly by their genesis, topography in relation to outcrops, migration conditions and biogenic factors. The Issyk-Kul basin is a natural uranium biogeochemical province, the regional uranium background is elevated and varies 
within $0.00012-0.00064 \%(14.9-79.6 \mathrm{~Bq} / \mathrm{kg})$ [6]. The specific activity of $238 \mathrm{U}$ in the soils of the city of Karakol is in the limit of 39.8-70.8 Bq/ $\mathrm{kg}$. Higher concentrations of uranium for mountain-forest soils of the Karakol natural park $78 \mathrm{~Bq} / \mathrm{kg}$ are probably associated with the peculiarities of the mountainous area of the territory (Table 3).

Table 3. The concentration of radionuclide in the soil of the city of Karakol $(\mathrm{Bq} / \mathrm{kg})$.

\begin{tabular}{|c|c|c|c|c|c|}
\hline \multirow{2}{*}{ Place of selection } & \multirow{2}{*}{ Type of soil } & $\mathrm{U} /{ }^{234} \mathrm{Th}$ & ${ }^{232} \mathrm{Th} / 228$ & ${ }^{40} \mathrm{~K}$ & ${ }^{137} \mathrm{Cs}$ \\
\hline & & \multicolumn{4}{|c|}{$(\mathrm{M} \pm \mathrm{m}) \mathrm{Bq} / \mathrm{kg}$} \\
\hline $\begin{array}{c}\text { Karakol Nature } \\
\text { Park }\end{array}$ & Mountain forest & $\begin{array}{c}70.8 \pm \\
5.3\end{array}$ & $\begin{array}{c}57.1 \pm \\
4.5\end{array}$ & $\begin{array}{c}624 \pm \\
5.5\end{array}$ & $\begin{array}{c}3.9 \pm \\
0.3\end{array}$ \\
\hline $\begin{array}{l}\text { "Kashka-Suu" } \\
\text { microdistrict }\end{array}$ & Grayish brown & $\begin{array}{c}39.8 \pm \\
2.3\end{array}$ & $\begin{array}{c}50.1 \pm \\
5.1\end{array}$ & $\begin{array}{c}523 \pm \\
5.4\end{array}$ & $\begin{array}{c}5.9 \pm \\
0.2\end{array}$ \\
\hline Victory Park & Grey-brown & $\begin{array}{c}78.1 \pm \\
4.9\end{array}$ & $\begin{array}{c}57.1 \pm \\
5.2\end{array}$ & $\begin{array}{c}606 \pm \\
6.3\end{array}$ & $\begin{array}{c}7.6 \pm \\
0.2\end{array}$ \\
\hline $\begin{array}{c}\text { "Voshod" } \\
\text { microdistrict }\end{array}$ & Grey-brown & $\begin{array}{c}55.5 \pm \\
3.2\end{array}$ & $\begin{array}{c}58.7 \pm \\
4.9\end{array}$ & $\begin{array}{c}552 \pm \\
5.2\end{array}$ & $\begin{array}{c}3.9 \pm \\
0.3\end{array}$ \\
\hline
\end{tabular}

\section{Conclusions}

1. The level of radiation background in terms of gamma radiation in the territory of the city of Karakol varies in the range of 16-30 microR/h and the radiation does not exceed established safety standards in the republic.

2. The specific activity of radionuclides $\left({ }^{238} \mathrm{U},{ }^{232} \mathrm{Th},{ }^{40} \mathrm{~K},{ }^{137} \mathrm{Cs}\right)$ varies within the natural background of the Issyk-Kul region.

3. The levels of total alpha and beta activity of radionuclides in the water of the Karakol River do not exceed the SanPin norm for drinking water.

4. The concentration of radionuclides is within the limits of background values in the bottom sediments, but a slightly increasing specific activity of radionuclide is observed in the estuary zone of the Karakol River.

\section{References}

1. V.K. Kadyrov, Hydrochemistry of the lake Issyk-Kul and its basin (Frunze, 1986)

2. B.M. Djenbaev, B.K. Kaldybaev, Methodical instructions: Sampling and sample preparation for determination of heavy metals in environmental objects (Bishkek, 2014)

3. N.G. Gusev, U.Y. Margulis, A.N. Marey, Dosimetric and radiometric methods (Moscow, 1966)

4. A.P. Vinogradov, Geochemistry of rare and scattered chemical elements in soils (Moscow, 1957)

5. V.A. Kovda. Biogeochemistry of the soil cover (Moscow, 1985)

6. I.E. Vorotnitskaya, Biogenic migration of uranium in the Issyk-Kul lake: the author's abstract of the dissertation of a Candidate of Biological Sciences (Moscow, 1988) 